Winter 2004

\title{
The Political Origins of the New Constitutionalism
}

\author{
Ran Hirschl \\ University of Toronto
}

Follow this and additional works at: https://www.repository.law.indiana.edu/ijgls

Part of the Constitutional Law Commons, International Law Commons, and the Law and Politics Commons

\section{Recommended Citation}

Hirschl, Ran (2004) "The Political Origins of the New Constitutionalism," Indiana Journal of Global Legal Studies: Vol. 11 : Iss. 1 , Article 4.

Available at: https://www.repository.law.indiana.edu/ijgls/vol11/iss1/4

This Symposium is brought to you for free and open access by the Law School Journals at Digital Repository @ Maurer Law. It has been accepted for inclusion in Indiana Journal of Global Legal Studies by an authorized editor of Digital Repository @ Maurer Law. For more information, please contact rvaughan@indiana.edu.

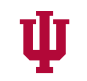

JEROME HALL LAW LIBRARY

INDIANA UNIVERSITY

Maurer School of Law
Blooming ton 


\title{
The Political Origins of the New Constitutionalism
}

\author{
Ran Hirschl
}

Over the past two decades the world has witnessed an astonishingly rapid transition to what may be called juristocracy. Around the globe, in numerous countries and in several supranational entities, fundamental constitutional reform has transferred an unprecedented amount of power from representative institutions to judiciaries. Most of these polities have a recently adopted constitution or constitutional revision that contains a bill of rights and establishes some form of active judicial review. National high courts and supranational tribunals meanwhile have become increasingly important, even crucial, policy-making bodies. To paraphrase Alexis de Tocqueville's observation regarding the United States, there is now hardly any moral, political, or public policy controversy in the new constitutionalism world that does not sooner or later become a judicial one.' This global trend toward the expansion of the judicial domain is arguably one of the most significant developments in late twentieth and early twenty-first century government. ${ }^{2}$

The global trend toward judicial empowerment through constitutionalization has been accompanied and reinforced by an almost unequivocal endorsement of the notion of constitutionalism and judicial review by scholars, jurists, and activists alike. As Ronald Dworkin-perhaps the most prominent constitutional

*Associate Professor of Political Science and Law, University of Toronto. Author's note: The article is based on material included in a forthcoming book of mine, entitled Towards Juristocracy: The Origins and Consequences of the New Constutionalism, ch. 2 (Harvard University Press, 2004). An outline of this article was presented at the "Globalization, Courts, and Judicial Power" symposium held at the Indiana University School of Law, Bloomington, A pril 11, 2003. I thank Professor Fred Aman and Dean Lauren Robel for the invitation to the symposium, Professor Ayelet Shachar for her thoughtful comments on an earlier draft of this article, as well as Paul Kaufman and the editors of the IJGLS for their editorial assistance.

1. Alexis De Tocqueville, Democracy in America 280 (Knopf 1945) (1835).

2. See, e.g., Ran Hirschl, Towards Juristocracy: The Origins and Consequences of the New Constitutionalism (2004); see also, e.g., J.H.H. Weiler, The Constitution of Europe: “Do the New Clothes Have an Emperor?" and Other Essays on European Integration 188-218 (1999) (describing the legitimacy of the European Court of Justice and the possible reasons for that legitimacy and acceptance); Martin Shapiro \& Alec Stone Sweet, On Law, Politics, and Judicialization (2002). See generally The Global Expansion of Judicial Power (C. Neal Tate \& Torbjörn Vallinder eds., 1995) (describing the expansion of judicial power in various democratic states); Alec Stone Sweet, Governing With Judges: Constitutional Politics in Europe (2000) (discussing the nature of European constitutional courts, their origins, and effects). 
theorist supportive of the worldwide convergence to constitutionalismobserves, every member of the European Community as well as other "mature democracies" (in Dworkin's words) subscribe to the view that democracy must protect itself against the tyranny of majority rule through constitutionalization and judicial review. ${ }^{3}$ Even countries such as Britain, New Zealand, Canada, and Israel-described until recently as bastions of Westminster-style parliamentary sovereignty-have embarked upon a comprehensive constitutional overhaul aimed at introducing principles of constitutional supremacy into their respective political systems.

What are the political origins of the sweeping convergence to constitutionalism and judicial review? The constitutionalization of rights and the corresponding establishment of judicial review are widely perceived as power-diffusing measures commonly associated with liberal or egalitarian values. As a result, studies of the political origins of the worldwide convergence to constitutionalism tend to portray it as the reflection of modern democracies' post-World War II coming to terms with, and deep commitment to, a "thick" notion of democracy (i.e. the notion that democracy has more to it than a mere adherence to the principle of majority rule), as a result of progressive social change or liberalizing political transformation, or simply as a reflection of their political leaders' benevolent devotion to an elevated vision of human rights. Unfortunately, however, most of the assumptions regarding the predominantly benign and progressive origins of constitutionalization remain for the most part untested and abstract.

This paper attempts to address this scholastic lacuna. It is divided into three parts. First, I survey and critically assess the main existing theories of constitutional transformation that purport to explain the causal mechanisms behind the constitutional entrenchment of rights and the establishment of judicial review. Second, I suggest that the trend toward constitutionalization is hardly driven by politicians' genuine commitment to democracy, social justice, or universal rights. Rather, it is best understood as the product of a strategic interplay among hegemonic yet threatened political elites, influential economic stakeholders, and judicial leaders. These three self-interested groups tend to form coalitions of legal innovation to determine the timing, extent, and nature of constitutional reforms. The trend towards judicial empowerment is a means by which pre-

3. Ronald Dworkin, A Bill of Rights for Britain 13-14 (1990) (hereinafter Rights for Britain). 
existing and ongoing socio-political struggles in a particular polity are carried out. I conclude by suggesting that the global trend toward juristocracy is part of a broader process, whereby political and economic elites, while they profess support for democracy, attempt to insulate policymaking from the vicissitudes of democratic politics.

\section{Conventional Theories of Constitutional Transformation}

Extant theories of constitutional transformation may be grouped into four major categories: the "democratic proliferation" thesis, evolutionist theories, furctionalist explanations, and institutional economics models.

\section{A. The "Democratic Proliferation" Thesis}

Most scholars of constitutional politics agree that there is a strong correlation between the recent worldwide expansion of the ethos and practice of democracy and the contemporaneous global expansion of judicial power. Indeed, with a few notable exceptions (such as Egypt and Pakistan, which maintain relatively autonomous and influential national high courts), the expansion of judicial power has taken place primarily in democratic polities or in countries undergoing transition to democracy. Over the past three decades, three major waves that established and consolidated democracy took place: in Southern Europe in the late 1970s, in Latin America in the 1980s, and in Central and Eastern Europe in the early 1990s. These movements brought with them an expansion of judicial power in most of these new democracies, primarily through the constitutionalization of rights and the establishment of relatively autonomous judiciaries and supreme courts armed with judicial review practices.

Indeed, by its very nature, the existence of a democratic regime implies the presence of a set of procedural governing rules and decision-making processes to which all political actors are required to adhere. The persistence and stability of such a system, in turn, requires at least a semi-autonomous, supposedly apolitical judiciary to serve as an impartial umpire in disputes concerning the scope and nature of the fundamental rules of the political game. Similarly, judicial review is a necessary component of viable democratic governance in multi-layered federalist countries (for example, the United States, Germany, Canada, India, and Australia), and in emerging supra-national polities (for example, the European Union). 
Moreover, the transition to and consolidation of democracy entails the establishment of some form of separation of powers, between the major branches of government, and between the central and provincial or regional legislatures. The existence of an independent and active judiciary appears to have been a necessary condition for, and an inevitable by-product of, the proliferation of democracy during the second half of the twentieth century. The expansion of judicial power has indeed been associated with political and economic liberalization in post-authoritarian or quasi-democratic polities.

However, the democratic proliferation thesis still presents major analytical difficulty. The widespread transition to democracy cannot provide a coherent explanation for the significant variations in judicial power among new democracies. Likewise, it fails to account for the significant variations in the timing, scope, and nature of the expansion of judicial power among established democracies.

What is more, the "expansion of democracy" thesis does not provide an adequate explanation for the "no apparent transition" constitutionalization scenario, in which constitutional reforms have neither been accompanied by, nor resulted from, any apparent fundamental changes in political or economic regimes. Some examples for this scenario would be the constitutional revolution and the corresponding establishment of active judicial review in Sweden (1979), Egypt (1980), Mexico (1994), and Thailand (1997); the enactment of the New Zealand Bill of Rights Act in 1990; the adoption of two new Basic Laws in Israel protecting a number of core rights and liberties; the adoption of the Human Rights Act in Britain in 1998; or the adoption of the Canadian Charter of Rights and Freedoms and the corresponding establishment of full scale judicial review in Canada in 1982. To these examples of judicial empowerment through constitutionalization at the national level we may add the proliferation of constitutionalization at the supra-national level (e.g. the European Union constitution). All of these polities have undergone a major constitutional reform over the past two decades. However, unlike many countries in Latin America or in the post-communist world, the dramatic constitutional changes in these polities have neither been accompanied by, nor resulted from, major changes in their political regimes.

\section{B. Evolutionist Theories}

The evolutionist approach to legal change stresses the inevitability of judicial progress and the importance of invisible and endogenous macro-factors in explaining the expansion of judicial power through constitutional reforms. 
Some evolutionist theories suggest that legal development is linked to a polity's passage from one socio-economic stage to another. Early legal transformation theorists such as Adam Smith argued that development of genuine contract and property concepts could only occur alongside the consolidation of agriculture. ${ }^{4}$ More recent evolutionist theories of legal transformation emphasize cultural variation among societies as a determinant of legal development. ${ }^{5}$ Other theories positing inevitable judicial progress and legal development by stages have also emerged within more general theories of economic and political development. ${ }^{6}$

The most widely-held thesis associated with this approach defines the trend toward the constitutionalization of rights and the fortification of judicial review as an inevitable by-product of a new and near universal prioritization of human rights in the wake of World War II. ${ }^{7}$ According to the generic version of this canonical view, the sweeping worldwide convergence to constitutionalism reflects modern democracies' genuine pre-commitment to entrenched, self-binding protection of basic rights and liberties in an attempt to protect vulnerable groups, individuals, beliefs, and ideas vis-à-vis the potential tyranny of political majorities; especially in times of war, economic crisis, and other incidents of political mass hysteria. The greatest proof of democracy's triumph in our times, it is argued, stems from the increasing acceptance and enforcement of the idea that democracy is not equivalent to majority rule; that in a real democracy (namely a democracy that subscribes to the constitutional supremacy principle rather than a democracy governed predominantly by the principle of parliamentary sover-

4. Adam Smith, An Inquiry into the Nature and Causes of the Wealth of Nations (1776).

5. See, e.g., Sir Henry Maine, Ancient Law (Dutton, Everyman's Library 1972) (1861); Emile Durkheim, The Division of Labor in Society 65-69 (Free Press of Glencoe 1964) (1893).

6. See e.g., S. N. Eisenstadt, Modernization: Protest and Change 38-40 (Wilbert E. Moore \& Neil J. Smelser eds., 1966) (suggesting the development of "autonomous legal systems" is essential to absorbing the complex challenges of change); Talcort Parsons, The Evolution of Societries 174-76 (1977) (discussing the importance of legal systems in integrating modern societies). See generally Readings in Social Evolution and Development (S. N. Eisenstadt ed., 1970) (discussing mechanisms of institutional change and the problems of modernization and development from a sociological perspective).

7. The works that adopt various versions of this approach are too numerous to cite. However, the most prominent exponent of this line of thought is Ronald Dworkin. See, e.g., Ronalo Dworkin, Taking Rights Seriously 147-49 (1978) (discussing the role of the legal system in protecting human rights); Rights for BRITAIN, supra note 3, at 13-23 (arguing the European Convention of Human Rights should be incorporated into its domestic law). 
eignty), minorities should possess legal protections in the form of a written constitution unchangeable even by an elected parliament. According to this view, the presence of an effectively enforced, written, and entrenched bill of rights is the crowning proof of a given polity's constitutional development. Judges who are removed from the pressures of partisan politics are responsible for enforcing such rights through active judicial review. Accordingly, the seemingly undemocratic characteristics of constitutions and judicial review are often portrayed as reconcilable with majority rule, or simply as necessary limits on democracy.

While providing a thoughtful and parsimonious explanation of the expansion of constitutionalism and judicial review over the past six decades, this version of the evolutionist approach does not have a coherent explanation for the great variance in the scope and timing of constitutionalization across the new constitutionalism world. Proponents of this conventional view fail to explain why Canada (1982), New Zealand (1990), Israel (1992), or Britain (1998) for example, converged to the post-World War II thick notion of democracy precisely in the years they did and not, say, a decade or two earlier. Moreover, from an empirical perspective it is unclear whether the adherence of a given polity to the conventional post-World War II notion of constitutionalism and judicial review indeed reflects that polity's commitment to basic rights and liberties. Norway and Sweden-two of the most developed and prosperous nations on earth-have long adhered to a relatively egalitarian conception of democracy, while being less than enthusiastic (to put it mildly) toward the American notion of rights and judicial review. Has this come at the expense of disregard for individual liberties in these countries? Hardly. The status of individual freedoms in the Netherlands-one of the few European countries that until very recently had stringently opposed the idea and practice of judicial review-has certainly not been lower than in the United States, which has had more than two centuries' use of a widely celebrated Bill of Rights and two centuries of active judicial review.

The conception of constitutional transformation that stems from the social contract school of thought views constitutions and judicial review as procedural devices that free and equal people might agree to voluntarily impose on themselves to protect their equal basic rights. ${ }^{8}$ Realizing the occasional temptation of

8. See generally Jon Elster, Ulysses and the Sirens: Studies in Rationality and IrrationalITY 36-111 (1979); Samuel Freeman, Constitutional Democracy and the Legitimacy of Judicial Review, 9 Law \& Phil. 327, 353 (1990); Stephen Holmes, Passions and Constraint: On the Theory of Liberal Democracy 134-77 (1995) (giving elaborations of the precommitment argument); Jeremy Waldron, Law and Disagreement (1998) (critiquing the precommitment argument). 
popular majorities to adopt measures that infringe on the basic rights of some, while not having an a priori indication of whose rights might be restricted by such potential measures, members of a polity might rationally choose to entrench the fundamental rules of the political game and the basic rights of its participants by granting a non-legislative body that is insulated from majoritarian politics the power to review legislation. In so doing, members of the polity (or its constituent assembly) provide themselves with precautions or pre-commitments against their own imperfections or harmful future desires, and tie themselves into their initial agreement on the basic rules and rights that specify their sovereignty. ${ }^{9}$ Proponents of this approach often regard the constitutionalization of rights and the establishment of judicial review as reflecting polities' and politicians' genuine "maturity" and deep commitment to a universal notion of human rights. As Cass Sunstein put it: "Democratic constitutions operate as 'precommitment strategies' in which nations, aware of problems that are likely to arise, take steps to ensure that those problems will not arise or that they will produce minimal damage if they do." 10

In its more empirically grounded variant, the evolutionist approach regards the constitutionalization of rights and the establishment of judicial review as fortifying the separation of powers between the executive, the legislature, and the judiciary. According to this view, there has been a general waning of confidence in technocratic government and planning, and a consequent desire to restrict the discretionary powers of the state. The result has been an expansion of judicial power over the past several decades." In its "counter-majoritarian" guise, this mainstream approach stresses that by increasing "access" points for special interest groups, the constitutionalization of rights and the establishment of active judicial review promote the diffusion of political power, add veto mechanisms, restrict maneuvering of policymakers, and limit the power of majorities in legislatures. ${ }^{12}$ According to this view, independent courts, especially

9. See Freeman, supra note 8, at 353.

10. Cass Sunstein, Designing Democracy: What Constitutions Do 241 (2001).

11. See Martin Shapiro, Courts: A Comparative and Political Analysis 111-25 (1981) (discussing the impact of administrative law on English courts); Martin Shapiro, The Success of Judicial Review, in Constitutional Dialogues in Comparative Perspective 193 (Sally J. Kenney, et al. eds., 1999).

12. See George Tsebelis, Decision-Making in Political Systems: Veto Players in Presidentialism, Parliamentarism, Multicameralism, and Multipartyism, 25 British J. Pol. SCI. 289, 323 (1995); see also Do Institutions Matter? Government Capabilities in the United States and Abroad 31 (R. Kent Weaver \& Bert A. Rockman eds., 1993). 
those armed with judicial review practices, not only monitor untrustworthy executive and legislative bodies, but also facilitate the political representation of diffuse but well-organized minorities. This representation creates opportunities for certain groups to participate in policy-making processes that might otherwise be closed to them in majoritarian parliamentary politics. ${ }^{13}$ Proponents of this approach therefore regard the constitutionalization of rights and the fortification of judicial review as the outcome of successful efforts by well-organized minority groups to protect themselves against the systematic threat of majoritarian political whims, and to increase their impact on public policy outcomes.

\section{Functionalist Explanations}

Like the evolutionist approach, functionalist (or systemic needs-based) explanations cast constitutional transformation as an organic response to pressures within the political system itself. These explanations emphasize the absence of human agency and the ineluctability embedded in any legal progress. However, they also recognize particular ways in which legal innovations can follow from demonstrations of social need. The best known functionalist explanations for legal change focus on increases in systemic efficiency as the end products of such change. Some institutional economists, for example, posit a systemic efficiencydriven process of legal transformation, in which inefficient legal rules would more likely be litigated while new efficient rules would persist once established..$^{14}$ Equivalent arguments have been made for legal changes in tort law and contract law, and even in the legal organization of a society to allow for modes of production that increase the rate of return on capital. Douglass North and Robert Thomas' analysis of the demise of feudalism in Europe illustrates the logic of this argument. During the Middle Ages, feudalism remained stable as long as land remained the scarce resource. Although lords could offer more rights to laboring serfs, it was not in their interest to do so. Following the Black Death, however, labor became the scarce resource. Lords, facing competition for labor for the first time, attempted to lure workers by offering them more attractive

13. See Jon Elster, Forces and Mechanisms in the Constitution-Making Process, 45 Duke L.J. 364, 377-79 (1995).

14. See Paul Rubin, Business Firms and the Common Law: The Evolution of Efficient RuLES iX (1983). 
working conditions. This in turn stimulated labor force mobility, thus destroying feudalism in Western Europe. ${ }^{15}$

In its most common version, the functionalist approach suggests that expansion of judicial power derives from a structural, organic political problem such as a weak, decentralized, or chronically deadlocked political system. The less functional the political system is in a given democracy, the greater the likelihood of expansive judicial power in that polity. ${ }^{16}$ Constitutionalization is seen as the best possible way of overcoming political "ungovernablity," and ensuring the unity and "normal" functioning of such polities. ${ }^{17}$ In its "consociational" variant, the needs-based explanation of constitutional transformation emphasizes political necessity in the development of mechanisms such as mutual veto and proportional representation, characterizing them as inevitable constitutional solutions that allow fragmented polities to function. According to this logic, expansion of judicial power in polities facing political polarization is the only institutional mechanism that enables opposition groups to monitor distrusted politicians and decision makers.

The explanation commonly given for the unprecedented judicialization of Israeli politics in recent years provides a perfect illustration of the account that invokes systemic needs as the main cause of judicial empowerment. In a marked change from the norms of Israel's early decades of independence, the judiciary, in particular the Israeli Supreme Court, has recently become one of the most significant actors in Israel's political arena. From the early 1990s on ward, the Court has increasingly exercised its power at the expense of politicians and administrators. The Court has gained the authority to review primary legislation, political agreements, and administrative acts, and to monitor almost every aspect of public life in Israel. Israeli society is characterized by deep social and cultural cleavages, ${ }^{18}$ as well as by a "political deadlock" between the two major electoral blocs

15. Douglass North \& Robert Thomas, The Rise of the Western World 9-18 (1973).

16. See Carlo Guarnieri et al., The Power of Judges: A Comparative Study of Court, and Democracy 160-81 (2002) (elaborating on this approach).

17. See Consolidating the Third Wave Democracies: Themes and Perspectives xvi-xviii (Larry Diamond et al. eds., 1997); see also Design in New Democracies: Eastern Europe and Latin America 1-11 (Arend Lijphart \& Carlos H. Waisman eds., 1996); Elster, supra note 13, at 371. See generally Designs for Democratic Stability: Studies in Viable Constitutionalism (Abdo I. Baaklini \& Helen Desfosses eds., 1997) (discussing the role of constitutionalism in establishing stability in various countries).

18. For example, between Jews and non-Jews, secular and religious Jews, and Ashkenazi and Mizrahi Jews. 
dating back to the late 1970s. According to the systemic needs explanation of judicial activism, the structural inability to deal with the social and cultural rifts besetting Israeli society and the stalemate faced by Israel's majoritarian politics corroded the authority of the Knesset and the government. This in turn led to the systemic dependency of the Israeli polity on a dominant, seemingly apolitical body of professional decision makers - the Supreme Court. ${ }^{19}$

Another functionalist (or systemic needs-based) explanation emphasizes the general proliferation in levels of government and the corresponding emergence of a wide variety of semi-autonomous administrative and regulatory state agencies as the main driving forces behind the expansion of judicial power over the past few decades. According to this thesis, independent and active judiciaries armed with judicial review practices are necessary for efficient monitoring of the ever expanding administrative state. Moreover, the modern administrative state embodies notions of government as an active policymaker, rather than a passive adjudicator of conflicts. It therefore requires an active, policy-making judiciary. ${ }^{20}$

Along the same lines, some accounts of the rapid growth of supranational judicial review in Europe over the past two decades portray it as an inevitable institutional response to complex coordination problems deriving from the systemic need to adopt standardized legal norms and administrative regulations across member-states in an era of converging economic markets. ${ }^{21}$ A similar "standardization" rationale may explain what may be called the "incorporation" scenario of constitutional reform. In this view, the constitutionalization of rights and the establishment of judicial review in member-states of supranational economic and political regimes (the European Union, for example), as well as signatory states to transnational trade and monetary treaties, occurred through the incorporation of international and trans- or supra-national legal standards into domestic law. Recent examples of this scenario of constitutionalization include

19. See Gad Barzilai, Between the Rule of Law and the Laws of the Ruler: The Supreme Court in Israeli Legal Culture, 152 INT'L Soc. Scı. J. 193, 206 (1997); Martin Edelman, The Judicialization of Politics in Israel, 15 Int'l Pol. Sci. Rev. 177, 184 (1994).

20. See Malcolm M. Feeley \& Edward L. Rubin, Judicial Policy Making and the Modern State: How the Courts Reformed America's Prisons 22-25 (1998) (analyzing policymaking as a legitimate and critical judicial function).

21. See Sweet, supra note 2, at 139; Alec Stone Sweet \& Thomas Brunell, Constructing a Supranational Constitution, 92 Am. PoL. Scr. Rev. 63, 65 (1998). 
the incorporation of the European Convention on Human Rights provisions into Danish law in 1993, into Swedish law in 1995, and into British law through the enactment in Britain of the Human Rights Act of 1998-the first rights legislation introduced in the United Kingdom in 300 years.

While the constitutional evolution and functionalist theories outlined above account for some factors contributing to the development of juristocracy, none analyzes the specific political vectors behind any of the constitutional revolutions of the past several years in a comparative, systematic, and detailed way. Moreover, none of these theories account for the precise timing of constitutional reform. If we apply these existing theories of constitutional transformation to a concrete example, they consistently fail to explain why a specific polity reached its most advanced stage of judicial progress at a specific moment and not, say, a decade earlier. Like the "democratic proliferation" thesis, both the "constitutionalization in the wake of World War II" thesis and its cor responding "constitutionalization as precommitment" argument fail to account for the significant variations in the timing, scope, and nature of constitutionalization. It is hard to see, for example, why members of the Canadian polity in 1982 or members of the Israeli polity a decade later, chose to take precautionary steps against their own imperfections precisely in the years they did, and not earlier or later. What is more, the constitutionalization as pre-commitment argument is based on a set of hypothetical and speculative presuppositions concerning the origins of constitutions and judicial review that at the very best provide an ex post facto normative justification for their adoption. Moreover, if a given polity is indeed "structurally ungovernable," it is difficult to see how the successful entrenchment of a bill of rights and the establishment of judicial review in that polity can be explained, given the failed earlier attempts to enact a constitutional catalogue of rights? Furthermore, both legal evolution and systemic needs-based theories of judicial transformation tend to ignore human agency, and the fact that legal innovations require legal innovators-people who make choices as to the timing, scope, and extent of legal reforms. Both of these kinds of explanation overlook the crucial self-interested intervention by those political power-holders who are committed to judicial expansion in an attempt to shape their institutional settings to serve their own agendas.

\section{Institutional Economics Models}

Another utilitarian approach-the institutional economics-derived theory of constitutional transformation-sees the development of constitutions and 
judicial review as mechanisms to mitigate systemic collective action concerns such as commitment, enforcement, and information problems. One such explanation sees the development of constitutions and independent judiciaries as an efficient institutional answer to the problem of "credible commitments." 22 Political leaders of any independent political unit want to promote sustainable longterm economic growth and encourage investment that will facilitate the prosperity of their polity. Two critical preconditions for economic development are the existence of predictable laws governing the marketplace and a legal regime that protects capital formation and ensures property rights. The entrenchment of constitutional rights and the establishment of independent judicial monitoring of the legislative and executive branches are seen as ways of increasing a given regime's credibility and enhancing the ability of its bureaucracy to enforce contracts, thereby securing investors' trust and enhancing their incentive to invest, innovate, and develop.

Indeed, as Max Weber noted, the fundamental building-block of every successful capitalist market is a secure "predictability interest." ${ }^{23}$ Without this, potential investors lack the incentive to invest. Scholars have shown how entrenched legal rights that enhance investors' trust have led to economic growth in various historical contexts. Douglass North and Barry Weingast, for example, have illustrated how limitations on rulers' power in early capitalist Europe increased legal security and predictability, thereby allowing certain polities to borrow capital from external lenders, who were protected by law from the seizure of their capital..$^{24}$ More recent empirical studies have established a statistical link between the existence of institutional limitations on government action (rigid constitutional provisions and judicial review, for example) and fast economic growth. ${ }^{25}$

22. See North \& Thomas, supra note 15; Oliver Williamson, Credible Commitments-Using Hostages to Support Exchange, 73 Am. Econ. Rev. 519 (1983); Barry Weingast, Constitutions as Governance Structures: The Political Foundations of Secure Markets, 149 J. of Inst ITUtional \& TheoretICAL ECon. 286 (1993); Barry Weingast, The Political Foundations of Democracy and the Rule of Law, 91 A. Pol. Sci. Rev. 245 (1997).

23. Max Weber, Economy and Society: An Outline of Interpretive Sociology 161-62 (Guenther Roth \& Claus Wittich, eds., University of California Press re-issue 1978) (1922).

24. Douglass C. North \& Barry R. Weingast, Constitutions and Commitment: The Evolution of Institutions Governing Public Choice in Seventeenth Century England, 49 J. of Econ. Hist. 803 (1989).

25. See Paul Mahoney, The Common Law and Economic Growth: Hayek Might Be Right, $30 \mathrm{~J}$. Legal Stud. 503 (2001); Rafael L.a Porta et al., Law and Finance, 106 J. of Pol. Econ. 1113 (1998); Rafael La Porta et al., Legal Determinants of External Finance, 52 J. Fin. 1131 (1997); Rafael La Porta et al., The Quality of Government, 15 J.L. Econ. \& OrG. 222 (1999). 
A second institutional economics explanation suggests that judicial review may constitute an efficient "fire alarm" mechanism for monitoring the bureaucracy. ${ }^{26}$ Legislators routinely delegate discretion over public policy programs to bureaucrats, but must try to ensure that these bureaucrats implement the programs as they were intended. Investments in measures that enhance judicial independence are accordingly interpreted as efforts by executive branch leaders to avoid the high costs of constant central supervision of bureaucratic agencies (or a "police patrol" mechanism). Adopting a decentralized "fire alarm" monitoring model allows those who feel they have been treated unfairly to sue through the courts. In a similar vein, recent studies have emphasized the utility of judicial review as a mechanism for conveying information to legislatures about judicial policy preferences vis-à-vis legislative policy preferences, as well as information concerning the actual effects of legislation. ${ }^{27}$ The information-conveying function of judicial review is likely to increase in cases of a priori, abstract judicial "preview," such as that exercised by the French Conseil Constitutionnel or by the Canadian Supreme Court in the reference procedure. ${ }^{28}$

Even if the constitutionalization of rights and the establishment of judicial review do indeed mitigate problems of information, commitment, and enforcement, as suggested by these institutional economics-driven theories for judicial empowerment through constitutionalization, these theories fail to explain how prosperous democratic polities managed to successfully address collective action problems prior to the establishment of judicial review. Constitutionalization, in other words, is not a necessary precondition for mitigating collective action and information problems. The adoption of constitutions and judicial review therefore cannot be explained solely by a polity's efficiency-driven quest for the mitigation of such problems. More importantly, these theories do not explain why a

26. See Matthew D. McCubbins \& Thomas Schwartz, Congressional Oversight Overlooked: Police Patrols Versus Fire Alarms, 28 Am. J. PoL. Scr. 165, 166 (1984); Matthew D. McCubbins et al., Structure and Process, Politics and Policy: Administrative Arrangements and the Political Control of Agencies, 75 VA. L. Rev. 431 (1989); Matthew D. McCubbins et al., Administrative Procedures as Instruments of Political Control, 3 J.L. Econ. \& ORG. 243 (1987).

27. See James Rogers, Information and Judicial Review: A Signaling Game of Legislative-Judicial Interaction, 45 Ам. J. PoL. Scr. 84 (2001).

28. Judicial review in Canada is not limited to review within the context of concrete adversary litigation. The reference procedure allows both the federal and provincial governments in Canada to refer proposed statutes or even questions concerning hypothetical legal situations to the Supreme Court or the provincial courts of appeal for an advisory (abstract) opinion on their constitutionality. 
certain polity would choose to adopt such efficient mechanisms at a particular point in time, and not much earlier.

\section{Thinking Critically about the Political Origins of Constitutionalization: The Strategic Approach and The Hegemonic Preservation Thesis}

A realist, strategic approach to judicial empowerment focuses on various power holders' self-interested incentives for deference to the judiciary. This approach makes four preliminary assumptions. First, legislative deference to the judiciary and judicial empowerment through constitutionalization do not develop separately from the concrete social, political, and economic struggles that shape a given political system. Indeed, the expansion of judicial power is an integral part and an important manifestation of those struggles, and cannot be understood in isolation from them. Second, when studying the political origins of constitutionalization (as well as the political origins of other institutional reforms), it is important to take into account events that did not occur and the motivation of political power holders for not behaving in certain ways. In other words, the political origins of constitutional reform cannot be studied in isolation from the political origins of constitutional stalemate and stagnation. Third, political and legal institutions produce differential distributive effects: they privilege some groups and individuals over others. Other variables being equal, prominent political, economic, and judicial actors are therefore likely to favor the establishment of institutional structures most beneficial to them. And fourth, because constitutions and judicial review hold no purse-strings, have no independent enforcement power, but nonetheless limit the institutional flexibility of political decision makers, the voluntary self-limitation through the transfer of policy-making authority from majoritarian decision-making arenas to courts seems, prima facie, to run counter to the interests of power-holders in legislatures and executives. Unless proven otherwise, the most plausible explanation for voluntary, self-imposed judicial empowerment is therefore that political, economic, and legal power holders who either initiate or refrain from blocking such reforms estimate that it serves their interests to abide by the limits imposed by increased judicial intervention in the political sphere.

Political power holders may profit from an expansion of judicial power in a number of ways. First, from the politicians' point of view, delegating policymaking authority to the courts may be an effective means of reducing decision- 
making costs, as well as shifting responsibility and thereby reducing the risks to themselves and to the institutional apparatus within which they operate. If delegation of powers can increase credit or reduce blame attributed to the politician as a result of the policy decision of the delegated body, then such delegation can be beneficial to the politician. ${ }^{29}$ The removal of policy-making power from legislatures and executives and its investiture in courts may become attractive for political power holders when disputes arise that they consider undesirable as open public debates, primarily because they present "no-win" political dilemmas (such as the dispute over abortion policy in the U.S., or the question of "who is a Jew" in Israel). As Mark Graber and others have shown, ruling national coalitions in the United States have been inclined to defer to the U.S. Supreme Court primarily when they have reached a political deadlock, faced a no-win decision, or have been unwilling or unable to settle contentious public disputes in the political sphere. Deference to the judiciary, in other words, is derivative of political, not judicial, factors. ${ }^{30}$

Second, when politicians seek to gain public support for contentious views by relying on national high courts' public image as professional and apolitical decision-making bodies, or when they regard a present or prospective "change of sea" in crucial majoritarian decision-making arenas as likely to put their own political status and policy preferences at risk, diverting policy-making responsibility to the courts may become an increasingly attractive option. The threat of losing grip on pertinent policy-making processes and outcomes may be a strong driving force behind attempts to transfer power to courts. Accordingly, a strategic, political power-oriented explanation for voluntary, self-imposed judicial empowerment through the constitutionalization and the establishment of judicial review suggests that political power holders who either initiate or refrain from blocking such reforms estimate that it enhances their absolute or relative political power vis-à-vis rival political actors and forces rival elements to abide by the limits imposed by expanded judicial power. Political actors who voluntarily establish institutions that appear to limit their institutional flexibility (such as constitutions and judicial review) may assume that the clipping of their wings under the new institutional structure will be compensated for by the limits it

29. See Stefan Voigt \& Eli M. Salzberger, Choosing Not to Choose: When Politicians Choose to Delegate Powers, 55 Int'l Rev. Soc. Scr. 289, 294 (2002). See also Morris P. Fiorina, Legislative Choice of Regulatory Forms: Legal Process of Administrative Process, 38 Pu в. Сногсе 33, 45-46 (1982).

30. See Mark A. Graber, The Nonmajoritarian Difficulty: Legislative Deference to the Judiciary, 7 Stud. Am. Pol. Dev. 35 (1993). 
might impose on rival political elements. In short, those who are eager to pay the price of judicial empowerment must assume that their position (absolute or relative) would be improved under a juristocracy. Such an understanding of judicial empowerment through constitutionalization as driven primarily by strategic political considerations may take a thin or a thick form.

\section{A. The Electoral Market Theory of Judicial Empowerment}

The thin version employs the party-based "electoral market" logic to explain judicial empowerment. In their seminal work of 1975, William Landes and Richard Posner argued that, other variables being equal, legislators favor the interest groups from which they can elicit the greatest investment through lobbying activities. A key element in maximizing such investments is the ability of legislators to signal credible long-term commitments to certain policy preferences. An independent judiciary's role in this regard is complementary to parliamentary procedural rules-it increases the durability of laws by making changes in legislation more difficult and costly. A judiciary that is overtly subservient to a current legislature (or expressly biased against it) can nullify legislation enacted in a previous session (or current legislation), thereby creating considerable instability in legal regimes. In such legally unstable settings, selling legislation to powerful interest groups may prove difficult from the politicians' point of view. The potential threat of instability or loss of mutual profits and power may therefore result in support for judicial empowerment vis-à-vis legislatures. ${ }^{31}$

Observing variations in the degree of judicial independence among industrial democracies, Mark Ramseyer and Eric Rasmussen develop Landes and Posner's argument into an "electoral market" model, which suggests that judicial independence correlates to the competitiveness of a polity's party system. ${ }^{32}$

31. William M. Landes \& Richard A. Posner, The Independent Judiciary in an Interest Group Perspective, 18 J.L. \& Econ. 875, 879 (1975); Eli M. Salzberger, A Positive Analysis of the Doctrine of Separation of Powers, or: Why Do We Have an Independent Judiciary? 13 INT'L Rev. L. \& Econ. 349, 358-59 (1993); Eli Salzberger \& Paul Fenn, Judicial Independence: Some Evidence from the English Court of Appeal, 42 J.L. \& Econ. 831, 832-33 (1999); Robert D. Tollison \& W. Mark Crain, Constitutional Change in an Interest-Group Perspective, 8 J. Legal Stud. 165, 166-67 (1979).

32. See J. Mark Ramseyer \& Eric Rasmusen, Why Are Japanese Judges So Conservative in Politically Charged Cases? 95 AM. Pol. Scı. Rev. 331, 333 (2001). See generally J. Mark Ramseyer, The Puzzling (In)Dependence of Courts: A Comparative Approach, 23 J. Legal Stud. 721 (1994) (discussing political uncertainty and politicians' corresponding desire for independent courts). 
When a ruling party expects to win elections repeatedly, the likelihood of judicial empowerment is low. Since rational politicians want long-term bargains with their constituents, they lack the incentive to support an independent judiciary when their prospects of remaining in power are high. However, when a ruling party has a low expectation of remaining in power, it is more likely to support an independent judiciary to ensure that the next ruling party cannot use the judiciary to achieve its policy goals. In other words, under conditions of electoral uncertainty, the more independent courts (or other semi-autonomous regulatory agencies) are, the harder it will be for the successive government to reverse the policies of the incumbent government. ${ }^{33}$ Therefore, in Japan, for example (where a single party ruled almost without interruption for more than four decades following World War II), judicial independence is weaker than it is in countries where there is an acknowledged risk that the party in power might lose control of the legislature in each election.

The electoral market thesis is quite insightful when analyzing the politics of constitution-making processes during periods of regime change and political transition. Judicial review, argues Tom Ginsburg, is a solution to the problem of uncertainty in constitutional design. By providing "insurance" to prospective electoral losers, judicial review can facilitate transition to democracy. ${ }^{34}$ As Pedro Magalhaes points out, "When the political actors that dominate the constitutionmaking process expect to lack control over legislatures in the future, judicial review of legislation may emerge as an institution designed to protect their interests." ${ }^{35}$

Consider the variance in constitutional court power among Taiwan, Mongolia, and South Korea - all of which underwent a transition to democracy in the late 1980s and early 1990s. In Taiwan, argues Tom Ginsburg, the democratization process was governed by a single dominant party (KMT) with an overwhelmingly powerful leader (Chiang Kai-shek). The result has been a very gradual constitutional reform ("Confucian constitutionalism" as Ginsburg calls

33. See Terry M. Moe, Political Institutions: The Neglected Side of the Story, 6 J.L. Econ. \& OrG. 213, 227 (1990).

34. Tom Ginsburg, Economic Analysis and the Design of Constitutional Courts, 3 Theoretical Inquiries L. 49, 54 (2002); see also Tom Ginsburg, Judicial Review in New Democracies: Constitutional Courts in Asian Cases (2003).

35. Pedro Magalhaes, The Limits to Judicialization: Legislative Politics and Constitutional Review in the Iberian Democracies 21 (2002) (unpublished Ph.D. dissertation, Ohio State University) (on file with Ohio State University Library). 
it), and the evolution of a relatively weak and politically dependent court (the Council of Grand Justices). In Mongolia, the former Communist Party was in a strong position during the constitutional negotiation stage, but was nonetheless unable to dictate outcomes unilaterally because of a newly emergent set of opposition parties. This has resulted in the creation in 1992 of a "middle of the road," quasi-independent court (the Constitutional $T_{\text {sets }}$ ). On the other hand, in Korea, constitutional transformation took place amidst embedded uncertainty as a result of political deadlock among three parties of roughly equal strength. The result was the 1988 creation of a relatively strong and to some extent independent constitutional court, as political insurance against electoral uncertainty.

Likewise, the transition to democracy in Spain and Portugal in the mid1970s was characterized by lack of a single core of post-authoritarian political power, thereby leading to the rapid adoption of strong constitutional review mechanisms. In Greece, by contrast, the post-authoritarian constituent process was dominated by a single party (Constantine Karamanlis' New Democracy), which enjoyed over 70 percent of seats in the assembly, and did not have to worry about elections following the approval of the new constitution. "The result was that Greece, with similar authoritarian and civil law legacies as Spain and Portugal, and involved in an almost simultaneous democratic transition, remained the only Southern European democracy without constitutional review of legislation. ${ }^{36}$ In a similar vein, the literature on the political origins of other relatively autonomous agencies suggests that the autonomy of, for example, central banks in advanced industrial countries is simply a function of government politicians' time horizons. The longer the horizon of their time in power, the more government politicians will desire the greatest possible control over economic policy. This implies a consequent loss of independence for the central bank. By this logic, short horizons or forthcoming elections can lead politicians who fear losing their office to increase central bank independence in order to limit the future options of their political opponents. ${ }^{37}$

While the electoral market "thin" strategic explanation contributes significantly to an understanding of the conditions under which judicial empowerment is more likely to occur, especially at times of political transition, it still does not provide a full understanding of constitutionalization and the accompanying

36. Id., at 127 .

37. See, e.g., John Goodman, The Politics of Central Bank Independence, 23 Comp. Pol. 329, 333 (1991). 
emergence of judicial review. For one, this model does not provide a full explanation for the rise of judicial power in the premier case of modern constitutionalization-the pre-electoral market, late eighteenth-century United States. More importantly, this model is based on a somewhat simplistic perception of politics as limited to the partisan electoral market. Such a minimalist understanding of politics does not capture the full picture of constitutional politics in ethnically or culturally divided "new constitutionalism" polities (e.g. Belgium or Canada), or in countries such as Israel, India, Egypt, Pakistan, Malaysia, or Turkey (to name but a few examples) where the fundamental tension between secularist, cosmopolitan values and religious particularism has been at the forefront of political struggle for decades. The political hegemony and cultural propensities of ruling elites and the urban intelligentsia in these and other fragmented polities have been constantly challenged by alternative worldviews, belief systems, and policy preferences. These nuanced and complex political struggles cannot be easily reduced to a thin view of politics as dominated by risk-averse politicians operating under conditions of political uncertainty at times of regime change.

What is more, from an analytical standpoint, there is a difference between at least two scenarios for judicial empowerment through constitutionalization: 1) constitution-making in "rebuilding the ship at sea" situations where most pertinent actors operate under a veil of systemic uncertainty and embedded unpredictability (as in most negotiated transitions from authoritarian to democratic regimes), and may therefore opt for judicial empowerment as a type of insurance in an unpredictable contractual environment; and 2) a distinctly different constitutionalization scenario, not necessarily linked to any formal political transition, regime change, or constitutional negotiations, whereby hegemonic yet threatened elites voluntarily initiate and carry out constitutionalization and judicial empowerment in an attempt to entrench or "lock in" their policy preferences against growing influence of historically disenfranchised or under-represented groups and interests in majoritarian decision-making arenas. Whereas the "thin" strategic thesis provides a compelling explanation for the emergence of judicial review under conditions of systemic uncertainty in new democracies, it misses a crucial driving force behind the second constitutionalization scenario (namely, constitutionalization as a form of self-interested political entrenchment of contested ideological worldviews, national identities, and policy preferences).

As I have shown elsewhere, the 1992 constitutional reform in Israel was initiated and carried out by an ad hoc cross-party coalition of leading Knesset 
members. ${ }^{38}$ Those supporting this reform included not only longstanding rivals from the country's two largest political parties— the Likud (Unity) party, which was in power in 1992, and the Labour party, which was the main opposition party in 1992 - but also representatives of the leftist opposition party Meretz and parliament members representing the policy preferences of the secular bourgeoisie. Clearly, this example demonstrates that the reductive partisan competition model fails to account for certain social and cultural forces. A more nuanced explanation of the political origins of constitutionalization is necessary if we are to fully understand judicial empowerment in such countries. This explanation must ignore neither agency nor the role of economic and judicial elites, and must reflect the political reality in internally fragmented, rule-of-law polities in a "thick" way that captures a broader picture than the mere electoral market aspect of politics.

\section{B. The Hegemonic Preservation Explanation of Judicial Empowerment}

I term this thick strategic explanation the "hegemonic preservation" thesis, and suggest that judicial empowerment through constitutionalization is best understood as the byproduct of a strategic interplay between three key groups: threatened political elites who seek to preserve or enhance their political hegemony by insulating policy-making processes from the vicissitudes of democratic politics; economic elites who may view the constitutionalization of certain economic liberties as a means of promoting a neoliberal agenda of open markets, economic deregulation, antistatism, and anticollectivism; and judicial elites and national high courts that seek to enhance their political influence and international reputation. In other words, strategic legal innovators-political elites in association with economic and judicial elites who have compatible interestsdetermine the timing, extent, and nature of constitutional reforms. To be sure, demands for constitutional change often emanate from various groups within the body politic. However, unless hegemonic political and economic elites, their parliamentary representatives, and the judicial elite envisage absolute or relative gain from a proposed change, the demand for that change is likely to be blocked or quashed.

38. See Ran Hirschl, The Political Origins of Judicial Empowerment through the Constitutionalization of Rights: Lessons from Four Constitutional Revolutions, 25 L. \& Soc. Inquiry 91 (2000); HiRsCHL, supra note 2. 
When facing possible threats to their policy preferences in majoritarian decision-making arenas (such as a growing influence on the part of historically disenfranchised or underrepresented groups and interests in democratically elected policy-making bodies), elites who possess disproportionate access to, and influence over, the legal arena may initiate a constitutional entrenchment of rights in order to transfer power to supreme or constitutional courts. Typically, such pro-constitutionalization elites comprise the urban intelligentsia, the legal profession, and the managerial class. They often represent historically hegemonic enclaves of political and economic power holders, who tend to adhere to an agenda of relative cosmopolitanism, open markets, formal equality, and Lockean-style individual autonomy. Based on the essential tendency of classic civil liberties to protect the private sphere (human or economic), as well as on the courts' record of adjudication and justices' ideological preferences, these elites can safely assume that their policy preferences will be less effectively contested.

This type of hegemonic preservation through the constitutionalization of rights or an interest-based judicial empowerment is likely to occur when the judiciary's public reputation for professionalism, political impartiality, and rectitude is relatively high; when judicial appointments are controlled to a large extent by hegemonic political elites; and when the courts' constitutional jurisprudence predictably mirrors the cultural propensities and policy preferences of these hegemonic elites. Under such conditions, judicial empowerment through the constitutionalization of rights and the establishment of judicial review may provide an efficient institutional means by which political elites can insulate their increasingly challenged policy preferences against popular political pressure, especially when majoritarian decision-making processes are not operating to their advantage.

This counterintuitive argument has striking parallels in works concerning the political origins of empowerment of other semi-autonomous institutions, such as central banks, environmental regulatory bodies, and supranational treaties and tribunals. Variance in the capacities of early central banking institutions in developing countries, for example, were shaped by the changing financial interests of those in a position to voluntarily delegate authority to central banks: government politicians and private banks. ${ }^{39}$ Similarly, varying degrees of

39. See, e.g., Sylvia Maxfield, Financial Incentives and Central Bank Authority in Industrializing Nations, 46 World Pol. 556, 564 (1993). 
support by existing firms toward proposed environmental regulatory policies can be explained by the different limits and costs such policies impose upon new firms. Because environmental regulation typically imposes more stringent controls on new firms, it restricts entry into the marketplace and potentially enhances the competitive position of existing firms. ${ }^{40}$

A similar rationale for judicial empowerment at the supranational level is put forward by the "intergovernmentalist" thesis concerning the evolution of the European Court of Justice (ECJ). ${ }^{41}$ According to this thesis, member states choose to create (and selectively abide by the limits imposed by) supranational institutions primarily because these institutions help them to surmount problems arising out of the need for collective action, and to overcome domestic political problems. National governments of the EU member states have not been passive and unwilling victims of the process of European legal integration; they consciously transferred power to the Court, and where the ECJ has been proactive, the member governments have supported this. Moreover, the selective implementation of ECJ rulings by member states derives from domestic political considerations by national governments (such as a greater willingness to implement ECJ judgments that favor certain constituencies whose political support is essential for governments and ruling coalitions).

Along the same lines, other works suggest that in newly established democracies in post-World War II Europe, governments committed to international human rights regimes (the European Court of Human Rights, for example) as a means of "locking-in" fundamental democratic practices in order to protect against future antidemocratic threats to domestic governance. ${ }^{42}$ Governments resorted to this tactic when the benefits of reducing future political uncertainty outweighed the "sovereignty costs" associated with membership in such supranational human rights enforcement mechanisms. The same logic may explain the voluntary incorporation of major international treaties and covenants protecting fundamental human rights and civil liberties into embattled democracies' constitutional law (as happened in Argentina in 1994); or the constitutionalization of rights and the corresponding establishment of full scale

40. See Michael Maloney \& Robert McCormick, A Positive Theory of Environmental Quality Regulation, 25 J.L. \& EcoN. 99 (1982).

41. See Geoffrey Garrett, The Politics of Legal Integration in the European Union, 49 InT'L Org. 171 (1998).

42. See Andrew Moravcsik, The Origins of Human Rights Regimes, 54 INT'L ORg. 217 (2000). 
constitutional review following years of political instability and recurring military coups d'état (as happened in Thailand in 1997). ${ }^{43}$ Likewise, the 1994 constitutional reform in Mexico (that included a substantial increase in the power and autonomy of the Supreme Court, revised the appointment procedures, and established full scale judicial review in that country) may be seen as a calculated attempt by the then-ruling party (Partido Revolucionario Institucional-PRI) to lock in its historic influence over Mexico's judicial sphere before the PRI's increasingly popular political opponents (and eventual winners of the 2000 presidential election) were able to gain control over the country's crucial policymaking arenas. ${ }^{44}$ Similarly, NAFTA's precision, for example, may be viewed as "part of the Mexican government's strategy to bind successor governments to its policies of economic openness." ${ }^{35}$ Hence, "governments may turn to international enforcement when an international commitment effectively enforces the policy preferences of a particular government at a particular point in time against future domestic political alternatives." ${ }^{\text {46 }}$ In other words, self-interested political incentives - rather than the altruistic considerations of political leaders, or universal commitment to a morally elevated conception of human rightsprovided the major impetus for the commitment by various countries to binding supranational human rights and free trade regimes.

Under specific circumstances, then, political power holders may choose to enhance their position by voluntarily tying their own hands. Such a strategic, counterintuitive self-limitation may be beneficial from the point of view of political power holders when the limits imposed on rival elements within the body politic outweigh the limits imposed on themselves.

However, influential pro-constitutionalization political elites in rule of law polities do not operate in a political or institutional vacuum. To effectively promote their judicial empowerment interests, they must secure the cooperation of economic and judicial elites with compatible interests. Indeed, judicial empowerment through the constitutionalization of rights may serve the interests of

43. See Pinai Nanakorn, Re-making of the Constitution in Thailand, 6 SINGAPORE J. OF INT'L \& CoMP. L. 90, 103 (2002).

44. See Pilar Domingo, Judicial Independence: The Politics of the Supreme Court in Mexico, $32 \mathrm{~J}$. Latin AM. Stud. 705, 714-15, 730 (2000); see also Bruce Rutherford, The Origins of Judicial Independence in the Developing World (paper presented at the APSA Annual Meeting, Philadelphia, 2003) (on file with author).

45. See Miles Kahler, The Causes and Consequences of Legalization, 54 INT'L ORG. 661, 663 (2000). 46. See Moravcsik, supra note 42, at 220. 
influential coalitions of domestic economic elites-powerful industrialists and corporations, who gain added impetus by global economic trends. Most constitutional catalogues of rights place boundaries on government action and protect the private sphere (human and economic) from unjustified state intervention. Moreover, the modern history of constitutional rights jurisprudence suggests that national high courts also tend to conceptualize the purpose of rights as protecting the private sphere from interference by the "collective," often understood as the state and its regulatory institutions. Economic elites may therefore view the constitutionalization of rights, especially property, mobility, and occupational rights, as a means of removing "market rigidities" (such as trade barriers and collective bargaining), promoting privatization and economic deregulation, or simply as a way of fighting what they often perceive to be the harmful "large government" policies of an encroaching state. ${ }^{47}$

Under specific circumstances, international political economy factors may also push domestic economic elites to advocate constitutionalization as a means of placing economic liberties and rules allowing for free movement of transnational capital beyond the reach of majoritarian control. ${ }^{48}$ For example, protection of the economic sphere through the constitutionalization of mobility, property, occupational and trade rights, as well as the establishment of independent judiciaries that function as checks on (often "unpredictable") domestic politics and (often "arbitrary") state action, have long been viewed by transnational economic bodies such as the World Bank, the World Trade Organization, and the International Monetary Fund as primary indicators of successful markets and sustained economic growth. ${ }^{49}$ The incorporation into domestic law of these

47. A close look at the landmark judgments protecting gay and lesbian rights-the hallmark of progressive constitutional rights jurisprudence in many new constitutionalism polities-suggests that these decisions fit a pre-existing pattern of protecting negative liberties simply by redefining an individual's sexual preference as an extension of his or her private sphere. The conduct in question should therefore enjoy the same protection from the public, the state, or an employer as any other personal trait. While these landmark judgments have been crucial in enhancing the everyday lives of millions of historically discriminated-against people, the establishment of the right to privacy or the "sameness" principle in the realm of sexual orientation simply expands the scope of personal characteristics that ought to be recognized as belonging to one's protected private sphere. The outcome is that sexual orientation, along with other personal characteristics, can serve neither as the basis for infringement upon one's right to privacy nor as a sole basis for differential treatment by the state and its organs.

48. See David Schneiderman, Investment Rules and the New Constitutionalism, 25 LAw \& Soc. INQUIRY 757 (2000).

49. See id. at $758-59$. 
and other legal norms endorsed by transnational trade and monetary regimes is often a prerequisite imposed upon countries striving to become members. New democracies (such as those in the former Eastern Bloc) that rely heavily on foreign aid and investment are likely to bow to pressure from leading western democracies, economic corporations, or transnational governing bodies to promote the rule of law by emulating the constitutional fundamentals of western democracies. Examples of these basic elements include the enactment of constitutional catalogues of rights and the establishment of relatively independent supreme courts armed with some type of active judicial review practices. Adopting a constitutional catalogue of rights and establishing judicial review may therefore serve as a means for a polity to demonstrate its willingness to accept the required legal standards for joining supranational economic regimes. As scholars have noted, the restriction of legislative power through the constitutionalization of rights and the establishment of judicial review may also enhance a given regime's international economic credibility and help prevent large-scale "capital flight." This latter consideration may explain the convergence to constitutionalism and judicial review by the African National Congress (ANC) in the early 1990s, despite its prospective control of government in the new South Africa, and in stark contrast to the socialist action program of the Freedom Charter advocated by the ANC throughout the apartheid era.

In short, the global trend towards constitutionalization concerns more than preservation of increasingly threatened values of core social groups. As Stephen Gill observes,

[n] ew constitutionalism is a macro-political dimension of the process whereby the nature and purpose of the public sphere in the OECD has been redefined in a more privatized and commodified way .... [It] can be defined as the political project of attempting to make transnational liberalism, and if possible liberal democratic capitalism, the sole model for future development. It is therefore intimately related to the rise of market civilization..$^{50}$

The transfer of power to the courts may also serve the interests of a supreme court seeking to enhance its political influence and international profile. As the

50. Stephen Gill, Globalization, Market Civilization, and Disciplinary Neoliberalism, 24 MILLENNIUM 399, 412 (1995). 
recent "strategic revolution" in the study of judicial decision making has established, judges may be precedent followers, framers of legal policies, or ideologydriven decision makers, but they are also sophisticated strategic decision makers who realize that their range of decision-making choices is constrained by the preferences and anticipated reaction of the surrounding political sphere. ${ }^{51}$ Judges tend to vote strategically to minimize the chances that their decisions will be overridden; if the interpretation that the judges most prefer is likely to elicit reversal by other branches, they will compromise by adopting the interpretation closest to their preferences that could be predicted to withstand reversal..$^{52} \mathrm{Ac}$ cordingly, quite a few landmark decisions of the U.S. Supreme Court have not been merely acts of professional, apolitical jurisprudence (as doctrinal legalistic explanations of court rulings often suggest) or reflections of its justices' ideological preferences and values (as "attitudinal" models of judicial behavior might suggest), but also a reflection of their strategic choices.

But short-term policy considerations represent merely one possible motivation for strategic behavior by courts. Supreme court judges may also be viewed as strategic actors to the extent that they seek to maintain or enhance their court's institutional position vis-à-vis other major national decision-making bodies. ${ }^{53}$ Courts may realize when the changing fates or preferences of other influential political actors, as well as gaps in the institutional context within which they operate, might allow them to strengthen their own position by extending the ambit of their jurisprudence and fortifying their status as crucial national policymaking bodies. ${ }^{54}$ As recent studies have shown, the establishment of an interna-

51. See William N. Eskridge, Reneging on History? Playing the Court/Congress/President Civil Rights Game, 79 Cal. L. Rev. 613 (1991); Lee Epstein \& Jack Knight, The Choices Judges Make 10 (1998); Lee Epstein \& Jack Knight, Towards a Strategic Revolution in Judicial Politics: A Look Back, A Look Ahead, 53 Pol. Res. Q. 625, 626 (2000). See generally Cornell Clayton \& Howard Gillman, Supreme Court Decision-Making: New Institutionalist Approaches (1999) (collecting several pieces describing different aspects of Supreme Court decision-making).

52. See Lawrence Baum, The Puzzle of Judicial Behavior 119 (John Aldrich et al. eds., 1997).

53. See Robert A. Dahl, Decision-Making in a Democracy: The Supreme Court as a National Policy-Maker, 6 J. Puв. L. 279 (1957).

54. Recent studies have identified a pattern of clusters of blunt antigovernment judgments occurring during periods of frail political regimes, most frequently during the last days of condemned dictatorships or toward the end of weak democratic governments. See, e.g., Gretchen Helmke, The Logic of Strategic Defection: Court-Executive Relations in Argentina Under Dictatorship and Democracy, 96 A M. Pol. Scr. Rev. 291 (2002). 
tional rule of law in Europe was driven in no small part by national judges' attempts to enhance their independence, influence, and authority vis-à-vis other courts and political actors. ${ }^{55}$

Expansion of judicial power through the constitutionalization of rights and judicial review may also support the interests of a supreme court seeking to increase its symbolic power and international prestige, by fostering its alignment with a growing community of liberal democratic nations engaged in judicial review and rights-based discourses. In this respect, it is important to acknowledge that the past several decades have seen an accelerating trend towards inter-court borrowing and the establishment of a globalized, non-U.S.-centered, judicial discourse. This trend has been described by Mary Ann Glendon as a "brisk international traffic in ideas about rights," carried on through advanced information technologies by high court judges from different countries. ${ }^{56}$ In its first landmark rights decision, ${ }^{57}$ the South African Constitutional Court examined in detail landmark rulings from Botswana, Canada, the European Court of Human Rights, Germany, Hong Kong, Hungary, India, Jamaica, Tanzania, the United Nations Committee on Human Rights, the United States, and Zimbabwe. As one commentator recently noted: "Constitutional interpretation across the globe is taking on an increasingly cosmopolitan character, as comparative jurisprudence comes to assume a central place in constitutional adjudication." 58 In short, "Courts are talking to one another all over the world." ${ }^{19}$ Similarly, judicial empowerment through constitutionalization may elevate the symbolic status of a fairly cohesive professional stratum of judges, law professors, human rights organizations, litigationoriented NGOs, as well as top lawyers and law firms. Not surprisingly, the legal profession has been one of the major advocates of judicial empowerment throughout the world of new constitutionalism.

55. See Karen J. Alter, Establishing the Supremacy of European Law: The Making of an International. Rule of Law in Europe (Paul Craig \& Grainne de Burca eds., 2001).

56. Mary Ann Glendon, Rights Talk: The Impoverishment of Political Discourse 158 (1991).

57. S v. Makwanyane, 1995 (3) SA 391 (CC) (determining the unconstitutionality of the death penalty).

58. Sujit Choudhry, Globalization in Search of Justification: Toward a Theory of Comparative Constitutional Interpretation, 74 IND. L.J. 819, 820 (1999).

59. Anne-Marie Slaughter, $A$ Typology of Transjudicial Communities, 29 U. RICH. L. Rev. 99, 99 (1994). See also Anne-Marie Slaughter, A Global Community of Courts, 44 Harv. Inr'L L.J. 191 (2003). 
However significant economic and judicial elites' own contributions to constitutionalization are, the support of influential political elites remains a key factor in this process. Supreme courts in relatively open, rule-of-law polities would prefer having an enhanced political influence and international profile. Likewise, economic elites have a near permanent interest in extended protection of the private sphere and entrenchment of economic freedoms. It is political power holders whose institutional room for political maneuvering is likely to be curtailed by constitutionalization and the corresponding expansion of judicial power. Thus, a transformation in the position of political power holders toward judicial empowerment-not the pro-constitutionalization stand of economic or judicial elitesis the primary catalyst and driving force behind constitutionalization.

Judicial power clearly does not fall from the sky. It is politically constructed. My account of judicial empowerment suggests that the constitutionalization of rights and the fortification of judicial review result from a strategic pact led by hegemonic yet increasingly threatened political elites seeking to insulate their policy preferences against the changing fortunes of democratic politics, in association with economic and judicial elites who have compatible interests. The changes that emerge reflect a combination of the policy preferences and professional interests of these groups.

Having shown that there are at least three distinct groups whose ability to gain power and influence is contingent upon judicial empowerment through the constitutionalization of rights, it becomes evident that the interest-based hegemonic struggle explanation does not depend upon the existence of any systemic social need. Nor does this thesis assume any necessary evolution in a progressive direction. This explanation is not deterministic, but actor-oriented and, unlike extant micro-foundational theories of judicial independence, it does not depend upon the competitiveness of the party system. While most existing theories of constitutional transformation focus on universal or organic macroexplanations for this increasingly common phenomenon, a realist approach to constitutionalization emphasizes human agency and specific political incentives as the major determinants of judicial empowerment. Such an approach suggests that the expansion of judicial power through the constitutionalization of rights and the establishment of judicial review reflects appropriation of the rhetoric of social justice by threatened elites to bolster their own position in the ongoing political struggles of a specific polity. 
Space limitations preclude full substantiation of the strategic approach to judicial empowerment, and more specifically of the hegemonic preservation thesis. ${ }^{60} \mathrm{~A}$ few examples should demonstrate its explanatory power.

Consider the miraculous convergence to constitutionalism and judicial review among South Africa's white political and business elites during the late 1980s and early 1990s---efforts that culminated with the adoption of an interim Bill of Rights in 1993, a final Bill of Rights in 1996, and the establishment of the new Constitutional Court in 1995. I will elaborate briefly on this very telling illustration of hegemonic preservation in action.

Calls for entrenched rights and for the establishment of active judicial review were strongly and consistently opposed by South Africa's ruling elites throughout the twentieth century. Until the late 1980s, the National Party leaders insisted that a Bill of Rights should not form part of any future constitutional order in South Africa, arguing that an emphasis on "individual interests" would be inconsistent with the political and religious tradition of Afrikanerdom, which preferred to emphasize "the State" and other supposed communitarian values over individual interests. The long-standing antagonism toward judicial review echoed former Boer President Kruger's famous century-old declaration that the power of the courts to test legislation was "a principle invented by the Devil!" 61

Accordingly, the South Africa Amendment Act of 1958 provided that "no court of law shall be competent to enquire into or to pronounce upon the validity of any law passed by parliament." Prime Minister Hendrick Verwoerd rejected calls for the adoption of an entrenched bill of rights by the Natal Provincial Council, stating that it would be unthinkable, as "no suggestion was made as to how rights could be effectively guaranteed without sacrificing the sovereignty of Parliament." ${ }^{" 62}$ The passage of the 1961 Republican Constitution secured the dominance of parliamentary sovereignty. Section 59 specifically incorporated the language of the South Africa Amendment Act, thus constitutionalizing the exclusion of the courts from substantive review, and explicitly limiting any judicial review over substantive legislative enactments affecting the language clause that guaranteed the equality of English and Afrikaans. A similar antipathy

60. See Hirschl, supra note 2, for a broader discussion.

61. H.R. Hahlo \& Ellison Kahn, The Union of South Africa, in 5 The British Commonwealth: The Development of its Laws and Constitutions 109 (George W. Keeton ed., 1960).

62. Alfred Cock rell, The South African Bill of Rights and the 'Duck/Rabbit', 60 MoD. L. Rev. 513, 522 (1997). 
toward the constitutionalization of rights and the establishment of active judicial review was reflected in the 1983 constitution.

When it became obvious that the apartheid regime could not be sustained by repression, the incentives of political and economic power holders among the white minority rapidly changed, and a sudden conversion to the supposed virtues of a bill of rights followed. Not surprisingly, this instance of a call to institute a bill of rights came from the old enemies of constitutionalization-the National Party government and other political representatives of the white minority, who suddenly appeared to "rediscover" the charms of entrenched rights and judicial review while hastily abandoning their historic commitment to parliamentary sovereignty. By reconciling themselves to the idea of an entrenched constitution that would include a constitutional catalogue of rights, as well as a constitutional court with powers of active judicial review, the apartheid government hoped to maintain some of the privileges enjoyed for so many decades by whites. Conscious judicial empowerment through constitutionalization followed.

In April 1986, only two years after publicly declaring that a Bill of Rights would be inconsistent with the political and religious tradition of Afrikanerdom, Minister of Justice H.J. Coetsee asked the South African Law Commission to investigate the subject of "group and human rights." The resulting research was made public in March 1989 when the Law Commission released a widely disseminated Working Paper, in which it recommended that South Africa should adopt an entrenched Bill of Rights. A further Interim Report on Group and Human Rights was published by the Law Commission in August 1991, in which it reiterated its support for the idea of adopting an entrenched bill of rights, and included a draft charter for discussion. ${ }^{63}$ Ironically, the Law Commission, on which not a single black person was represented, concluded its report by declaring that "No matter who governs this country, it goes without saying that if we are to avoid dictatorship-even the dictatorship of a democratic majority - we need such a bill." ${ }^{64}$ The overnight abandonment of the antiBill of Rights rhetoric by the National Party and other representatives of the white elite was completed in February 1990, when President F.W. de Klerk officially announced in Parliament that a future constitution would need to include a Bill of Rights as proposed in the Law Commission's Working Paper. And as

63. S. Afr. L. Comm'n, Working Paper on Group and Human Rights Law, No. 25, Project 58 (1989).

64. Id. at 296. 
the old saying goes, the rest of the story of the new South Africa's rapid convergence to constitutionalism is history.

By 1991, most white constituencies had accepted the idea of a Bill of Rights in its entirety, adopting a view that called for the abandonment of traditional parliamentary supremacy and the establishment of judicial review. The National Party (NP) eventually published its own version of a "Charter of Fundamental Rights" in February 1993, keenly advocating a transitional bill of rights that would constrain the power of the National Assembly in which the NP would have a minority representation. The draft proposal of the Charter stated, inter alia, that:

[T]he object of the Charter is not to create or regulate legal relations amongst persons themselves. The main purpose of the Charter is to protect individuals against abuse of power by state authorities. It is not intended as a direct source of rights and obligations among individuals themselves, for example, to allow for a dissatisfied employee to sue his employer on the grounds of alleged infringement of his fundamental rights. The Charter is a standard with which the acts of state authorities towards a citizen must comply. ${ }^{65}$

Both the 1993 interim Constitution and the 1996 final Constitution possess two distinct features that are unprecedented in South African constitutional history. First, the Constitution entrenches constitutional supremacy and a sovereign Bill of Rights. Legislative and executive acts of government can now be declared invalid if they are found to violate fundamental human rights. Second, the Constitution established a Constitutional Court with final jurisdiction over constitutional matters. Roelf Meyer, the NP government's chief constitutional negotiator, summed up the outcome of the first stage of constitutionalization from the NP's point of view: "[W]e wanted to build in an assurance that the Constitution be based on the principles of a constitutional state. We wanted individual rights and a Constitutional Court. So we got what we wanted." ${ }^{66}$

65. Dennis Davis, Deconstructing and Reconstructing the Argument for a Bill of Rights Within the Context of South African Nationalism, in The Post Apartheid Constitutions 207 (2001).

66. Roelf Meyer, From Parliamentary Sovereignty to Constitutionality: The Democratization of South Africa, 1990 to 1994, in The Post Apartheid Constitutions, supra note 65, at 58. 
Throughout the pre-1996 negotiations, the NP and the Democratic Party (both parties holding a base of substantial business support), advocated the constitutional entrenchment of the strongest possible protection of individual property rights (including explicit anti-redistribution provisions), alongside the narrowest viable protection of workers' right to strike, unionize, and bargain collectively. The NP won out conclusively on the property rights front, ensuring that the state was barred from implementing "arbitrary or unreasonable" land redistribution measures. ${ }^{67}$ Moreover, any departure from the Bill of Rights' "property clause" is subject to judicial scrutiny of its constitutionality vis-à-vis the Constitution's "limitation clause." ${ }^{68}$ In sum, the white elite and its parliamentary representatives, faced with the inevitable prospect of an ANC-controlled parliament, endorsed a bill of rights, a "property clause," and active judicial review as means of fencing off certain aspects of their privilege from the reach of majoritarian politics.

Attempts by the political representatives of white settlers and domestic elites to protect their joint interests through the constitutionalization of rights, especially property rights, is not new to the African continent. As recent work has shown, British colonial decision makers and domestic elites did not trust that the new political authorities in many soon-to-be-decolonized African countries would protect the interests of their principal constituencies-white settlers, urban intelligentsia, and foreign investors-and were therefore eager to establish seemingly autonomous judicial systems and land registration apparatus, as well as to adopt entrenched constitutional catalogues of rights in these countries prior to completion of the decolonization process. ${ }^{69}$ While for many years Britain was unwilling to incorporate the provisions of the European Convention on Human Rights into its own legal system (let alone to enact a constitutional bill of rights of its own), it did enthusiastically promote the entrenchment of Convention rights in the "independence constitutions" of newly self-governing African states, as devices for protecting established interests from the "whims" of independent majoritarian politics. The constitutionalization of rights in the Gold

67. Section 25(1) of the 1996 Constitution reads: "No one may be deprived of property except in terms of law of general application, and no law may permit arbitrary deprivation of property."

68. See section 25(8). The "limitation clause" is section 36(1) of the 1996 Constitution.

69. See Kathryn Firmin-Sellers, The Politics of Property Rights, 89 Am. Pol. ScI. Rev. 867 (1995); Kathryn Firmin-Sellers, The Transformation of Property Rights in the Gold Coast 91 (1996) [hereinafter Property Rights in the Gold Coast]; Vivien Hart, The Contagion of Rights: Constitutions as Carriers, in Identity, Rights, and Constitutional Transformation 39 (Patrick $\mathbf{J}$. Hanafin \& Melissa S. Williams eds., 1999). 
Coast (Ghana) in 1957, Nigeria in 1959, and Kenya in 1960 (to name only three examples) followed this pattern.

And I have not yet mentioned the timing of the June 1991 constitutionalization of rights in British-ruled Hong Kong, which took place less than two years after the British Parliament had ratified the Joint Declaration on the Question of Hong Kong, whereby Britain was to restore Hong Kong to China in July 1997. Nor have I discussed the political origins of the Turkish constitutional revolution of 1983, and the key role the Turkish Constitutional Court has played in preserving the strictly secular nature of Turkey's political system, by continuously outlawing anti-secularist popular political movements in that country (including the 2001 dissolution of the pro-Islamic Virtue Party, which was the country's main opposition group at the time) ${ }^{70}$ or the establishment of judicial review in Egypt in 1979 amidst a resurgence in Islamic fundamentalism, and the crucial role of the Egyptian Supreme Constitutional Court in advancing a relatively liberal interpretation of Islamic Shari'a rules. ${ }^{71}$

As I have shown elsewhere, the hegemonic preservation thesis may shed light on the political vectors behind the constitutional revolutions in formerly Westminster-style polities such as Canada (the adoption of the Charter of Rights and Freedoms in 1982 as part of a broader strategic response by Canada's federalist, anglophone, business-oriented elites to the growing threat of Quebec separatism and the rapidly changing demographics of the Canadian society); ${ }^{72}$ and

70. This decision was released on June 21,2001. Virtue had 103 seats of Turkey's 550 -seat parliament. In its decision, the Court accepted the charge that the Virtue Party was violating the fundamental secular principles of the Turkish constitution by using religious symbols for political purposes. Moreover, the Court ordered the treasury to confiscate the party's funds and property. In a similar fashion, in January 1998, the Turkish Constitutional Court ordered the dissolution of the Welfare Party (Rafah), Virtue's predecessor as Turkey's major Islamic opposition party.

71. In 1980, Article 2 of Egypt's Constitution was amended to allow for principles of Islamic jurisprudence to become the main source of legislation in Egypt. This meant that no legislation could be passed that contravened Islamic legal principles. Following the establishment of judicial review in 1979 and the 1980 constitutional amendment, the Egyptian Supreme Constitutional Court has increasingly been called upon to determine the constitutionality of legislative and administrative acts on the basis of their adherence to the principles of the Shari'a. The question before the Court in all of these cases has concerned which principles of the Sharia possess determinative and absolute authority. In many of these cases, the Court adopted a fairly progressive interpretation of Shari'a rules. See, e.g., Wassel v. Minister of Education (the Niq'ab [veil] Case), No. 8 of the 17th judicial year (Egypt S.Ct. May 18, 1996); the Riba [usury or intercst] Case, No. 20, 1st judicial year (Egypt S.Ct. May 4, 1986).

72. See Hirschl, supra note 38 , at 91. 
Israel (the adoption in 1992 of two new Basic Laws protecting a number of core rights and liberties, and the corresponding establishment of constitutional review in 1995 as part of a strategic response by Israel's hegemonic secular bourgeoisie who had been rapidly losing its historical grip on Israel's majoritarian decision-making arenas). ${ }^{73}$ All of these instances of judicial empowerment through constitutionalization did not stem from constitutional negotiations under a veil of systemic uncertainty at times of political transition. Rather, they were the outcome of a deliberate strategy undertaken by hegemonic yet threatened political elites (in association with economic and judicial elites sharing compatible interest) who found strategic drawbacks in adhering to democratic decision-making processes. From an instrumental perspective, judicial review may facilitate effective transition to democracy by providing insurance to prospective electoral losers. However, it must not be overlooked that "hegemonic preservation" through constitutionalization is driven in no small part by forces and interests antithetical to democratic governance.

In sum, as one of those people who "seldom think of politics more than 18 hours a day," ${ }^{74}$ I have advanced here a strategic notion of judicial empowerment through constitutionalization as driven primarily by political interests to insulate certain policy preferences from popular political pressures. The causal mechanisms behind the trend toward constitutionalization and judicialization in divided polities have not been adequately delineated by the major theories of constitutional transformation. The "democratic expansion," evolutionist, functionalist, "new institutionalist," and electoral market models cannot provide a full explanation for the recent history of constitutional entrenchment of rights and judicial review in many new constitutionalism polities. The trend toward judicial empowerment through constitutionalization, while admittedly different in each country in scope and context, can be more productively analyzed in terms of an interest-based hegemonic preservation approach. According to this approach, judicial empowerment through the constitutionalization of rights and the establishment of judicial review can be understood as a conscious strategy undertaken by threatened political elites seeking to preserve or enhance

73. See id. at 106-115; Ruth Gavison, Constitutional and Political Reconstruction? Israel's Quest for a Constitution, 18 Int'l Soc. 53 (2003); Gershon Shafir \& Yoav Peled, Being Israeli: The Dynamics of Multiple Citizenship 260-77 (2002).

74. Attributed to Lyndon B. Johnson, 36th President of the United States. Lyndon B. Johnson, at www.quoteworld.org/(last visited August 19, 2003). 
their hegemony by insulating policy making from popular political pressures, and supported by economic and judicial elites with compatible interests. Moreover, what I have called the "hegemonic preservation" thesis serves as a reminder that seemingly humanitarian constitutional reforms often mask an essentially self-serving agenda. The constitutionalization of rights, in other words, is often not so much the cause or a reflection of a progressive revolution in a given polity, as it is a means by which pre-existing and ongoing sociopolitical struggles in that polity are carried out.

Moreover, in many countries (such as Israel, New Zealand, and South Africa), the intentional empowerment of the judiciary by threatened but still dominant political powers has been strongly supported by influential coalitions of domestic neoliberal economic forces who view the constitutionalization of rights as a means of promoting economic deregulation, as well as by national high courts seeking to enhance their political influence and international profile. Indeed, the contemporaneous emergence of a neoliberal economic order and the movement toward constitutionalization in these countries is anything but accidental or fortuitous. On the contrary, the two trends go hand in hand and in fact complement each other; they share a common adherence to a "small government" world-view, a commitment to an expansive conceptualization of the private sphere, and an uneasy attitude, even sheer hostility, toward the less than predictable political sphere.

\section{The Hegemonic Preservation Thesis Beyond the National Level}

The hegemonic preservation thesis may help us understand judicial empowerment through constitutionalization as part of a broader trend whereby crucial policy-making functions are increasingly insulated from majoritarian control. As we have seen, the world seems to have been seized by a craze for constitutionalization and judicial review. The transformation of judicial institutions into major political actors has not been limited to the national level; at the supranational level, the European Court of Justice interprets the treaties upon which the European Union is founded, and has been awarded an increasingly important status by legislators, executives, and judiciaries in EU member states dealing with inter-state legal and economic disputes. The European Court of Human Rights in Strasbourg, the judicial arm of the forty-one-member Council of Europe, has in effect become the final court of appeal on human rights issues for most of Europe. The judgments of these European courts (as well as of other 
supranational tribunals such as the Inter-American Court of Human Rights) carry great weight and have forced many countries to incorporate transnational legal standards into their domestic legal system. The recent introduction of a proposed comprehensive constitution for the $\mathrm{EU}$, the upcoming territorial expansion of the EU, and the consequent expansion in the jurisdiction of the Union's courts and legal regime not only transformed European politics; it extended the exercise of judicial power to new or charged political settings. Present calls for the adoption of a global constitution, the emergence of the new EU Constitution, and the establishment of a permanent international tribunal for war crimes and human rights violations also suggest that the law and courts in general, and the constitutionalization of rights in particular, are increasingly becoming key factors in international politics.

Over the past several decades, the delegation of policy-making authority to semi-autonomous, professional bodies has also expanded in other, non-judicial realms. In many countries, for example, there has been a general move toward granting greater independence to central banks. Countries such as Belgium, Britain, France, Spain, Brazil, and Argentina have all significantly increased the autonomy of their respective central banks. In these and many other countries, democratically elected governments no longer have exclusive control over monetary policy making. Likewise, supranational policy-making bodies have gained authority over many aspects of everyday life in the European continent over the past three decades. This process has included the establishment of the new European Central Bank, the recent launch of a single European currency, the emergence of a complex nexus of supranational legal provisions regulating production, import, and export of goods, as well as taxation and customs throughout the European continent, the reconstruction and expansion of NATO - not to mention the creation of new transnational bodies dealing with immigration, natural resources, labor relations, food and drug licensing and regulation, consumer protection, environmental preservation, and so on. A similar process has taken place, albeit at a slower pace, in other continents (for example, the emergence of transnational trade treaties such as NAFTA in North America, MERCOSUR in South America, ASEAN in Asia, and APEC in the AsiaPacific region), as well as at the intercontinental level (for example, the rise of supranational bodies such as the International Monetary Fund and the World Trade Organization, which monitor substantive aspects of global trade and international monetary policies). Almost all of these supranational entities have established powerful judicial or quasi-judicial binding adjudication appara- 
tuses. In short, a large-scale transfer of crucial policy-making prerogatives from majoritarian decision-making arenas to relatively insulated domestic and transnational policy-making bodies has been rapidly established over the past thirty years.

This has occurred alongside growing popular demands for political representation; the spread throughout the globe of universal suffrage (which has included an erosion of the historical dependence of voting rights upon property ownership, gender, race or ethnic origin); a global decline in politically formalized group-based discrimination and segregation; a rapid growth in the level of education and political awareness within the general population; an unprecedented influx of immigration to prosperous western countries over the past three decades, which threatens to change the foundational demographics in these countries; increasing demands by ethnic and religious communities for greater self-government; and above all, the growing presence of new or historically recessive interests and policy preferences (for example, environmentalism, disarmament, and multiculturalism) in crucial majoritarian policy-making arenas. Consequently, the institutions of democratic governance now operate in a profoundly different environment than that in which they were founded.

All of these recent developments imply profoundly more versatile electorates, and consequently, an increasing potential threat to established interests and hegemonic cultural, economic, and political worldviews. The expanded representation of such "peripheral" interests has further emphasized the tension between powerful centripetal forces of convergence acting on the state from outside (such as formal democracy, economic neoliberalism, global capitalism, an international stock exchange culture, media production and consumption controlled to a large extent by a handful of international mega-conglomerates); and re-emerging centrifugal forces of divergence acting on it from inside (such as regionalism, differentiated citizenship, and growing economic inequality). In the face of such challenges, supporters of dominant but increasingly threatened interests may choose to limit the policy-making authority of majoritarian decision-making arenas by gradually transferring authority to relatively insulated, professional policy-making institutions such as national high courts, central banks, trans-national trade and monetary organizations, and supranational bureaucracies and tribunals.

By keeping popular decision-making mechanisms at the forefront of the formal democratic political processes, while simultaneously shifting the power to formulate and promulgate certain policies from majoritarian policy-making 
arenas to semi-autonomous professional policy-making bodies, those who possess disproportionate access to, and have a decisive influence upon such bodies, minimize the potential threat to their hegemony. I would therefore suggest that the current global trend toward judicial empowerment through constitutionalization is part of a broader process, whereby self-interested political and economic elites, while they profess support for democracy and sustained development, attempt to insulate policy making from the vagaries of democratic politics. Given the increasing presence of previously excluded groups and interests in majoritarian policy-making arenas, this large-scale insulation of policy making is perhaps the least dangerous modus vivendi for threatened elites. Put bluntly, it can best be understood as an attempt to defend established interests from the potential threats posed by the voices of cultural divergence, growing economic inequality, regionalism, and other centrifugal forces that have been given a public platform through the proliferation of representative democracy. This counterintuitive insight concerning the origins and consequences of one of the most significant political phenomena of our times-the transition to juristocracy-serves as a rather grim testament as to the real nature of twentyfirst century constitutional democracy. 